SIVANESAN I; KYOUNG KE; KYOUNG KM; YOUNG KE; PARK SW. 2015. Somatic embryogenesis and plant regeneration from zygotic embryo explants of onion. Horticultura Brasileira 33: 441-447. http://dx.doi.org/10.1590/S0102-053620150000400006

\title{
Somatic embryogenesis and plant regeneration from zygotic embryo explants of onion
}

\author{
Iyyakkannu Sivanesan; Kim E Kyoung; Kim M Kyoung; Ko E Young; Se W Park \\ Konkuk University, Seoul, Republic of Korea; isvanesan@gmail.com
}

\begin{abstract}
The study was undertaken to examine the effect of two synthetic auxins on somatic embryogenesis and plant regeneration from mature embryo explants of 16 onion cultivars. Cotyledons were removed from the embryos and remaining portions were cultured on MS medium supplemented with $1.0 \mathrm{mg} / \mathrm{L} 2,4-\mathrm{D}$ and $5.0 \mathrm{mg} / \mathrm{L}$ picloram alone or in combination $(1.0 \mathrm{mg} / \mathrm{L} 2,4-\mathrm{D}+2.5 \mathrm{mg} / \mathrm{L}$ picloram $)$ to produce embryogenic callus. MS medium supplemented with 5.0 $\mathrm{mg} / \mathrm{L}$ picloram was found to be the best one for both embryogenic callus induction $(85 \%)$ and callus diameter $(3.8 \mathrm{~mm})$. Of the 16 cultivars studied, Yeoeuijuhwang exhibited the lowest frequency of embryogenic callus induction (50.5\%), whereas all the other 15 cultivars showed more than $60 \%$ embryogenic callus induction. Scanning electron micrograph (SEM) analysis of embryogenic callus showed all stages of somatic embryos such as globular, scuetellar and coleoptilar. Plant regeneration was significantly affected by the composition of embryogenic callus induction medium. The greatest frequency of somatic embryo conversion was obtained from embryogenic callus developed in MS medium with 2,4-D (70.1\%) followed by picloram $(38.9 \%)$ and $2,4-\mathrm{D}+$ picloram $(34.5 \%)$. The germinated plantlets were further developed on the half-strength MS medium containing $3 \%$ sucrose and were acclimatized in the culture room with $98 \%$ survival rate.
\end{abstract}

Keywords: Allium cepa, auxin, embryogenic callus, in vitro propagation, picloram.

\section{RESUMO}

Embriogênese somática e regeneração de plantas a partir de explantes de embriões zigóticos de cebola

O estudo foi realizado para examinar o efeito de duas auxinas sintéticas na embriogênese somática e na regeneração de plantas a partir de explantes de embriões maduros de 16 cultivares de cebola. Os cotilédones foram removidos a partir dos embriões e as porções restantes foram cultivadas em meio MS suplementado com 1,0 $\mathrm{mg} / \mathrm{L}$ de 2,4-D e 5,0 mg/L de picloram sozinho ou em combinação (1,0 mg/L de 2,4-D + 2,5 mg/L de picloram) para produzir calos embriogênicos. Verificou-se que o meio MS suplementado com $5,0 \mathrm{mg} / \mathrm{L}$ de picloram foi o melhor tanto para a indução de calo embriogênico (85\%) quanto para o diâmetro do calo (3,8 mm). Das 16 cultivares estudadas, Yeoeuijuhwang exibiu a menor freqüência de formação de calos embriogênicos $(50,5 \%)$, ao passo que todas as outras 15 cultivares apresentaram mais de $60 \%$ de indução de calos embriogênicos. A análise dos calos por micrografia eletrônica de varredura (SEM) mostrou todas as fases dos embriões somáticos, tais como as fases globular, escutelar e coleoptilar. A regeneração de plantas foi significativamente afetada pela composição do meio de indução de calos embriogênicos. A maior frequência de conversão de embriões somáticos foi obtida a partir do calo embriogênico desenvolvido em meio MS com 2,4-D (70,1\%) seguido por picloram (38,9\%) e 2,4-D + picloram (34,5\%). As plântulas germinadas foram desenvolvidas no meio contendo metade da dose de MS, com $3 \%$ de sacarose e foram aclimatizadas em ambiente de cultura com $98 \%$ de taxa de sobrevivência.

Palavras-chave: Allium cepa, auxina, calo embriogênicos, propagação in vitro, picloram.

(Recebido para publicação em 5 de fevereiro de 2015; aceito em 8 de maio de 2015) (Received on February 5, 2015; accepted on May 8, 2015)

$\mathrm{O}$ nion (Allium cepa) is one of the most important vegetable crops in the world. It has been used as an herbal drug in traditional medicine for the treatment of various ailments. Onion is reported to contain dietary fiber, fructooligosaccharides, flavonoids and alk(en)yl cystein sulphoxides (Benítez et al., 2011). Compounds obtained from onion have been reported to possess antiasthmatic, antibiotic, anticarcinogenic, antioxidant, antiplatelet, and antithrombotic activities (Griffiths et al., 2002; Santas et al., 2010; Albrechtova et al., 2012). Onion has been cultivated worldwide, with an annual production of 85 million tons. The consumption of onion is increasing sharply in recent years. The productivity of onion is adversely affected by various abiotic and biotic factors. The crop improvement through conventional breeding has certain limitations. Onion will not cross readily with other Allium species (Griffiths et al., 2002). Further, it takes two years to produce seeds due its biennial nature.

Plant tissue culture technique has become an important tool for crop improvement. Development of efficient plant regeneration protocol is a prerequisite for genetic transformation studies. Several studies on onion reported plant regeneration from bulb (Hussey \& Falavigna, 1980), immature flower bud (Pike \& Yoo, 1990), immature 
zygotic embryo (Marinangeli et al., 2005), mature flower bud (Luthar \& Bohanec, 1999), and mature zygotic embryo (Zheng et al., 2001). However, plant regeneration is highly dependend upon the cultivars studied (Tanikawa et al., 1998). On the other hand, somatic embryogenesis (SE) is considered useful tool for genetic manipulation and large scale propagation. In addition, this process is also considered as a most suitable system for physiological and morphological studies in plant during morphological development, and conservation of desired genotypes through mass propagation (Lelu-Walter et al., 2013). SE is mainly associated with culture conditions, concentration of plant growth regulators in the culture medium and stress factors. The addition of high levels of auxin to the culture medium is often required to induce somatic embryos in most plant species. However, development beyond the globular stage was inhibited by maintaining the same induction medium. Thus, for promoting further growth and development of SES it is necessary to subculture the embryos to the PGRfree medium. SE in onion has been reported previously using embryo (van der Valk et al., 1992; Eady et al., 1998; Zhang et al., 2004), flower bud (Luthar \& Bohanec, 1999), radical (Aswath et al., 2006), shoot apex (Ramakrishnan et al., 2013), and seed (Saker, 1997). These studies have demonstrated the influence of culture media, genotype and plant growth regulators on SE. The frequency of SE is mainly affected by genotype (Saker, 1997; Eady et al., 1998). Saker (1997) demonstrated that 2,4-dichlorophenoxyacetic acid $(2,4-D)$ was suitable for the induction of SE in embryo explants of onion. On the other hand, Eady et al. (1998) reported the induction of SE from embryo explants of onion cultured on medium with picloram. Thus, in this study we investigated the effect of auxins on somatic embryogenesis and plant regeneration from mature embryo explants of 16 onion cultivars.

\section{MATERIAL AND METHODS}

Plant material and surface sterilization - Seeds of 16 onion (Allium сера) cultivars (Geumgodeahwang, Geumokhwang, Dabonghwang, Bonganhwang, Chunjudaego, Chunjuhwang, Chunjujunggo, Yeoeuijuhwang, Okayhwang, Yangchunhwang, Younganhwang, Seouldaego, Spring Gold, Turbo, Manchuhwang, and Higuma) were obtained from Onion Research Institute, Gyeongsangnam-do Agricultural Research and Extension Services, Changnyeong, Korea. The characteristics of onion cultivars are given in Table 1. Seeds were thoroughly washed with distilled water. Then, they were surface sterilized in $70 \%$ ethanol for 30 seconds, immersed in $2 \%$ sodium hypochlorite for 20 minutes with agitation, washed with sterile distilled water for five times, and stored in sterile distilled water at $4^{\circ} \mathrm{C}$. After 24 hours, seeds were rinsed two times with sterile distilled water. Seeds were dissected and mature embryos were isolated.

Embryogenic callus induction - Cotyledons were removed from the embryos and remaining portions (Figure 1A) were cultured in $90 \times 15$ $\mathrm{mm}$ Petri dish containing $25 \mathrm{~mL}$ of Murashige \& Skoog (MS) medium supplemented with $1.0 \mathrm{mg} / \mathrm{L} 2,4-\mathrm{D}$, $5.0 \mathrm{mg} / \mathrm{L}$ picloram or $1.0 \mathrm{mg} / \mathrm{L} 2,4-\mathrm{D}$ $+2.5 \mathrm{mg} / \mathrm{L}$ picloram. The medium consisted of MS nutrients and vitamins (Murashige \& Skoog, 1962) with 3\% sucrose and solidified with $0.8 \%$ plant agar (Duchefa Co., Netherlands). The $\mathrm{pH}$ of the medium was adjusted to 5.8 before autoclaving at $121^{\circ} \mathrm{C}$, for 20 minutes. The cultures were maintained at $25 \pm 2^{\circ} \mathrm{C}$ in darkness and subcultured onto the same fresh medium at 4 weeks. For each treatment, 60 embryos were used and the experiment was repeated three times. The percentage of embryogenic callus induction and diameter of callus were recorded after 8 weeks of culture.

Scanning electron microscopy (SEM) analysis - Embryogenic calli (8 weeks old) were fixed in 5\% paraformaldehyde, $5 \%$ glutaraldehyde and $0.2 \mathrm{M}$ phosphate buffer ( $\mathrm{pH} 7.2)$ at $4^{\circ} \mathrm{C}$. After 4 hours, the fixed samples were washed three times with 0.1 M phosphate buffer solutions for 15 minutes. The samples were fixed again in $2 \% \mathrm{OsO}_{4}$ at $4{ }^{\circ} \mathrm{C}$ for 2 hours, and $0.2 \mathrm{M}$ phosphate buffer ( $\mathrm{pH}$ 7.2) for 4 hours. Then, they were washed with $0.1 \mathrm{M}$ phosphate buffer solution for 15 minutes with 3 times, and dehydrated with ethanol series of 15 minutes exposures to $50,60,70,80$, and $90 \%$. Finally exposure to $100 \%$ ethanol was repeated three times. The samples were critical-point dried and coated with gold before observation. They were analyzed using scanning electron microscope (JSM-5410LV, JEOL, Japan) operating at $15 \mathrm{kV}$.

Plant regeneration - Embryogenic calli obtained from each induction medium were separately transferred to hormone-free MS medium containing $3 \%$ sucrose. The cultures were maintained at $25 \pm 2^{\circ} \mathrm{C}$ under a 16 hours photoperiod with light of $45 \mu \mathrm{mol} / \mathrm{m}^{2} / \mathrm{s}$. For each experiment, 30 embryogenic calli were used and the experiment was repeated three times. The percentage of plant regeneration was calculated after 8 weeks of culture.

Plantlet development and acclimatization - Regenerated plantlets were transferred to half-strength MS medium containing 3\% sucrose for further shoot and root development. After 4 weeks, plantlets were removed from the culture, washed thoroughly with distilled water, planted in 10 $\mathrm{cm}$ pots containing peat, perlite and vermiculite (1:1:1), kept under culture room conditions, and irrigated two days interval with quarter-strength MS salt solution. Plantlet survival was recorded after 4 weeks.

Data analysis - Experiments were set up in a completely randomized design and repeated three times. The percentage of SE induction was determined by counting explants forming embryogenic callus from the total number of the cultured explants. The percentage of plant regeneration was determined by counting the number of embryogenic calli forming plantlets out of the total number of calli cultured. In each treatment, 60 explants or 30 calli were used and the experiment was repeated three times. Data were subjected to analysis of variance (ANOVA) by using SAS program (Release 9.1, 
SAS Institute, NC, USA). Differences between the mean values were assessed with Duncan's multiple range test at $\mathrm{p}<0.05$. Percentage values were subjected to arcsine transformation before variance analysis (Compton 1994).

\section{RESULTS AND DISCUSSION}

Effect of auxins on embryogenic callus induction - The induction of embryogenic callus from various explants of onion has been best achieved by incorporating auxins such as 2,4-D and picloram into the culture medium (Phillips \& Luteyn, 1983; van der Valk et al., 1992; Saker, 1997; Eady et al., 1998; Zhang et al., 2004; Aswath et al., 2006; Ramakrishnan et al., 2013). However, the frequency of callus induction was low (33-60\%). Furthermore, the callus induction is mostly dependent on genotype. In this study, we investigated the effects of 2,4-D and picloram on embryogenic callus induction from zygotic embryo of 16 Korean onion cultivars. The zygotic embryo explants formed callus within 2 weeks of culture on the MS medium supplemented with 2,4-D and picloram alone or in combination (Figure1B). After 4 weeks of culture, three morphologically different callus types were observed: compact, friable and transparent types. Yellowish compact and nodular structures were observed after 8 weeks of culture in all studied cultivars (Figure 1C). However, the frequency of embryogenic callus induction and growth of callus varied among the cultivars (Table 2). MS medium supplemented with 5.0 $\mathrm{mg} / \mathrm{L}$ picloram was found to be best for both embryogenic callus induction $(85 \%)$ and callus diameter $(3.8 \mathrm{~mm})$. Phillips \& Luteyn (1983) reported that picloram was superior than 2,4-D for callus induction. Eady et al. (1998) also reported that picloram was suitable for callus induction in onion, but the mean frequency of callus induction was low $(48 \%)$. The major difference between the protocols is use of MS medium instead of MS nutrients with $B_{5}$ vitamins. Of the 16 cultivars studied, Yeoeuijuhwang exhibited the lowest frequency of embryogenic callus induction (50.5\%), whereas all the other 15 cultivars showed more than $60 \%$ embryogenic callus induction in all studied media.

Table 1. Details of onion cultivars used in this study (detalhes de cultivares de cebola utilizadas neste estudo). Seoul (Korea), Konkuk University, 2014.

\begin{tabular}{lccc}
\hline Cultivar & \multicolumn{3}{c}{ Cultivation group } \\
\cline { 2 - 4 } & $\begin{array}{c}\text { Sowing in } \\
\text { spring }\end{array}$ & $\begin{array}{c}\text { Sowing in } \\
\text { autumn }\end{array}$ & $\begin{array}{c}\text { Ripening } \\
\text { stage }\end{array}$ \\
\hline Geumgodeahwang & - & 0 & Mid and late \\
Geumokhwang & - & 0 & Mid and late \\
Dabonghwang & - & 0 & Mid and late \\
Bonganhwang & - & 0 & Mid and late \\
Chunjudaego & - & 0 & Late \\
Chunjuhwang & - & 0 & Mid and late \\
Chunjujunggo & - & 0 & Mid and late \\
Yeoeuijuhwang & - & 0 & Mid and late \\
Okayhwang & - & 0 & Mid and late \\
Yangchunhwang & - & 0 & Extremely early \\
Younganhwang & - & 0 & Mid and late \\
Seouldaego & - & 0 & Mid and late \\
Spring Gold & o & - & Early \\
Turbo & - & 0 & Mid \\
Manchuhwang & - & 0 & Late \\
Higuma & 0 & - & Early \\
\hline & & & \\
\hline
\end{tabular}

'Geumgodeahwang', 'Dabonghwang', 'Chunjudaego', 'Okayhwang', 'Yangchunhwang', 'Younganhwang', 'Turbo', and 'Higuma' showed more than $90 \%$ embryogenic callus induction. The highest callus diameter was observed in 'Geumokhwang' $(4.55 \mathrm{~mm})$ and the lowest was in 'Yeoeuijuhwang' $(2.31 \mathrm{~mm})$ when the explants were cultured on MS medium supplemented with $5.0 \mathrm{mg} / \mathrm{L}$ picloram or $1.0 \mathrm{mg} / \mathrm{L} 2,4-\mathrm{D}$ and $2.5 \mathrm{mg} / \mathrm{L}$ picloram, respectively (Table 2 ). In the medium containing 2,4-D, the frequency of embryogenic callus induction ranged from 32.6 to $95.3 \%$. In 'Bonganhwang', 'Chunjudaego', 'Yeoeuijuhwang', 'Spring Gold', 'Manchuhwang', and 'Higuma' combination of 2,4-D and picloram enhanced the frequency of embryogenic callus induction than 2,4$\mathrm{D}$ or picloram.

Embryogenic callus induction is dependent on genotype and plant growth regulators. Auxins have been proven to be the most effective for embryogenic callus induction from various explants of onion (Saker, 1997; Eady et al., 1998; Zhang et al., 2004; Aswath et al., 2006; Ramakrishnan et al., 2013).

SEM analysis of embryogenic callus - The processes of SE have been documented in onion using 2,4-D (Saker, 1997) and picloram (Eady et al., 1998). However, the morphology of somatic embryos has not been well studied. In this study, the morphology of embryogenic callus (8 weeks old) was examined under microscope. Various stages of somatic embryos were observed on the surface of the embryogenic callus through light microscope (Figure 2A). SEM analysis also confirmed the presence of various stages of somatic embryos such as globular (Figure 2B), scuetellar and coleoptilar (Figures 2C, 2D). The callus mediated SE has also been confirmed through SEM analysis in other monocotyledons (Ozias-Akins \& Vasil, 1982, 1983; Chaudhury \& Qu, 2000; Cabral et al., 2011).

Plant regeneration from embryogenic callus - The embryogenic callus showing somatic embryos and plant regeneration were transferred to the hormone-free MS medium containing $3 \%$ sucrose. The regeneration potential 
of embryogenic callus was significantly affected by the callus induction medium. The plant regeneration frequency ranged from 15.8 to $87.2 \%$ (Table 3 ). 'Geumgodeahwang', 'Geumokhwang' and 'Chunjuhwang' showed more than
Table 2. Effects of auxins on embryogenic callus induction (\%) and callus growth from zygotic embryos of 16 onion cultivars after 8 weeks of culture (efeito de auxinas na formação de calo embriogênico e de desenvolvimento do calo a partir de embriões zigóticos de 16 cultivares de cebola após 8 semanas de cultura). Seoul (Korea), Konkuk University, 2014.

\begin{tabular}{|c|c|c|c|c|}
\hline \multirow{2}{*}{ Cultivars } & \multicolumn{3}{|c|}{ Treatments } & \multirow[b]{2}{*}{ Mean } \\
\hline & 1 & 2 & 3 & \\
\hline Geumgodeahwang & $91.6 \pm 2.4$ & $94.7 \pm 1.3$ & $84.7 \pm 1.2$ & $90.3 \pm 5.1 \mathrm{ab}$ \\
\hline Geumokhwang & $60.5 \pm 1.5$ & $81.1 \pm 3.0$ & $65.8 \pm 1.7$ & $69.1 \pm 10.7 \mathrm{e}$ \\
\hline Dabonghwang & $86.3 \pm 3.0$ & $90.5 \pm 3.5$ & $83.2 \pm 2.6$ & $86.6 \pm 3.7 \mathrm{a}-\mathrm{d}$ \\
\hline Bonganhwang & $76.8 \pm 2.2$ & $87.9 \pm 2.1$ & $94.0 \pm 2.4$ & $86.2 \pm 9.0 \mathrm{a}-\mathrm{d}$ \\
\hline Chunjudaego & $95.3 \pm 2.4$ & $96.8 \pm 2.2$ & $98.0 \pm 1.0$ & $96.7 \pm 1.3 \mathrm{a}$ \\
\hline Chunjuhwang & $89.5 \pm 1.5$ & $86.3 \pm 1.0$ & $88.3 \pm 3.2$ & $88.0 \pm 1.6 \mathrm{a}-\mathrm{c}$ \\
\hline Chunjujunggo & $74.2 \pm 1.7$ & $83.7 \pm 1.4$ & $66.8 \pm 2.1$ & $74.9 \pm 8.5 \mathrm{de}$ \\
\hline Yeoeuijuhwang & $32.6 \pm 1.0$ & $39.5 \pm 2.0$ & $50.5 \pm 1.4$ & $40.8 \pm 9.0 \mathrm{f}$ \\
\hline Okayhwang & $78.4 \pm 1.2$ & $93.6 \pm 2.4$ & $74.2 \pm 3.4$ & $82.0 \pm 9.1 \mathrm{~b}-\mathrm{d}$ \\
\hline Yangchunhwang & $91.1 \pm 2.0$ & $97.9 \pm 1.2$ & $86.8 \pm 3.7$ & $91.9 \pm 5.6 \mathrm{ab}$ \\
\hline Younganhwang & $85.3 \pm 3.7$ & $92.6 \pm 3.4$ & $90.0 \pm 3.9$ & $89.3 \pm 3.7 \mathrm{a}-\mathrm{c}$ \\
\hline Seouldaego & $74.7 \pm 1.2$ & $87.9 \pm 3.2$ & $78.9 \pm 2.2$ & $80.5 \pm 6.7 \mathrm{~b}$-e \\
\hline Spring Gold & $77.9 \pm 2.1$ & $67.9 \pm 2.2$ & $87.4 \pm 2.4$ & $77.7 \pm 9.8 \mathrm{c}-\mathrm{e}$ \\
\hline Turbo & $82.4 \pm 2.6$ & $90.1 \pm 3.0$ & $80.5 \pm 2.9$ & $84.3 \pm 6.2 \mathrm{a}-\mathrm{d}$ \\
\hline Manchuhwang & $76.3 \pm 1.7$ & $83.7 \pm 1.4$ & $89.0 \pm 2.0$ & $83.0 \pm 6.4 \mathrm{~b}-\mathrm{d}$ \\
\hline Higuma & $84.7 \pm 2.4$ & $85.8 \pm 3.2$ & $95.8 \pm 3.0$ & $88.7 \pm 6.1 \mathrm{a}-\mathrm{c}$ \\
\hline \multirow[t]{2}{*}{ Mean } & $78.6 \pm 14.9 \mathrm{~b}$ & $85.0 \pm 14.1 \mathrm{a}$ & \multicolumn{2}{|l|}{$82.1 \pm 12.6 \mathrm{ab}$} \\
\hline & \multicolumn{4}{|c|}{ Callus diameter $(\mathrm{mm})$} \\
\hline Geumgodeahwang & $3.48 \pm 0.12$ & $3.83 \pm 0.15$ & $3.22 \pm 0.13$ & $3.51 \pm 0.30 \mathrm{bc}$ \\
\hline Geumokhwang & $3.32 \pm 0.12$ & $4.55 \pm 0.11$ & $3.13 \pm 0.24$ & $3.66 \pm 0.77 b$ \\
\hline Dabonghwang & $3.05 \pm 0.08$ & $4.04 \pm 0.13$ & $3.07 \pm 0.12$ & $3.38 \pm 0.57 \mathrm{~cd}$ \\
\hline Bonganhwang & $2.74 \pm 0.10$ & $3.36 \pm 0.18$ & $2.50 \pm 0.11$ & $2.86 \pm 0.44 \mathrm{~g}$ \\
\hline Chunjudaego & $3.89 \pm 0.18$ & $4.42 \pm 0.12$ & $3.64 \pm 0.11$ & $3.98 \pm 0.40 \mathrm{a}$ \\
\hline Chunjuhwang & $3.24 \pm 0.11$ & $3.71 \pm 0.15$ & $2.95 \pm 0.13$ & $3.30 \pm 0.38 \mathrm{c}-\mathrm{e}$ \\
\hline Chunjujunggo & $2.88 \pm 0.12$ & $3.36 \pm 0.17$ & $2.67 \pm 0.08$ & $2.97 \pm 0.35 \mathrm{fg}$ \\
\hline Yeoeuijuhwang & $2.38 \pm 0.16$ & $2.83 \pm 0.28$ & $2.31 \pm 0.08$ & $2.50 \pm 0.28 \mathrm{~h}$ \\
\hline Okayhwang & $2.85 \pm 0.20$ & $3.71 \pm 0.16$ & $2.81 \pm 0.09$ & $3.12 \pm 0.51 \mathrm{~d}-\mathrm{g}$ \\
\hline Yangchunhwang & $3.42 \pm 0.13$ & $4.26 \pm 0.16$ & $3.55 \pm 0.07$ & $3.74 \pm 0.45 \mathrm{ab}$ \\
\hline Younganhwang & $3.06 \pm 0.12$ & $3.42 \pm 0.23$ & $2.65 \pm 0.13$ & $3.04 \pm 0.39 \mathrm{e}-\mathrm{g}$ \\
\hline Seouldaego & $3.08 \pm 0.19$ & $3.65 \pm 0.22$ & $2.86 \pm 0.15$ & $3.19 \pm 0.41 \mathrm{~d}-\mathrm{f}$ \\
\hline Spring Gold & $2.97 \pm 0.11$ & $4.06 \pm 0.22$ & $2.97 \pm 0.11$ & $3.33 \pm 0.62 \mathrm{c}-\mathrm{e}$ \\
\hline Turbo & $3.08 \pm 0.10$ & $3.62 \pm 0.14$ & $2.69 \pm 0.18$ & $3.13 \pm 0.47 \mathrm{~d}-\mathrm{g}$ \\
\hline Manchuhwang & $3.55 \pm 0.10$ & $4.31 \pm 0.25$ & $3.36 \pm 0.18$ & $3.74 \pm 0.50 \mathrm{ab}$ \\
\hline Higuma & $3.28 \pm 0.12$ & $4.04 \pm 0.19$ & $2.77 \pm 0.10$ & $3.36 \pm 0.63 \mathrm{~cd}$ \\
\hline Mean & $3.14 \pm 0.36 \mathrm{~b}$ & $3.82 \pm 0.46 \mathrm{a}$ & $2.94 \pm 0.37 \mathrm{c}$ & \\
\hline
\end{tabular}

Treatment 1=2,4-D (1.0 mg/L); Treatment 2= Picloram $(5.0 \mathrm{mg} / \mathrm{L})$; Treatment 3=2,4-D $(1.0 \mathrm{mg} / \mathrm{L})+$ Picloram $(2.5 \mathrm{mg} / \mathrm{L})$. Average values followed by same letters within a column are not significantly different according to Duncan's multiple range test $(\mathrm{p}<0.05)$ (valores médios seguidos de letras iguais na coluna não diferem entre si, pelo teste de Duncan, $5 \%$ ).
$80 \%$ of plant regeneration, whereas 'Yeoeuijuhwang' exhibited low regeneration frequency $(56.4 \%)$. The highest frequency of plant regeneration was observed in 'Geumokhwang' $(87.2 \%)$. Of the various calli studied, the embryogenic calli induced on MS medium containing 2,4-D had high regenerative potential. Similar result has also been reported in onion (van der Valk et al., 1992; Luthar \& Bohanec, 1999). In contrast, somatic embryos of onion produced on MS medium containing low concentration of 2,4-D (1.0 mg/L) failed to develop into plantlets (Saker, 1997). In this study, the greatest frequency of somatic embryo conversion was obtained from callus developed in MS medium with 2,4-D (70.1\%) followed by picloram (38.9\%) and 2,4-D + picloram (34.5\%). 2,4-D has been reported to be the most efficient synthetic auxin for SE in onion (van der Valk et al., 1992; Saker, 1997; Zheng et al., 1998; Luthar \& Bohanec, 1999; Ramakrishnan et al., 2013). On the other hand, Eday et al. (1998) and Phillips \& Luteyn (1983) found that picloram was more efficient for SE than 2,4-D. In most of the studies, somatic embryos of onion converted to plantlets on the culture medium without hormones (van der Valk et al., 1992; Zheng et al. 1998). In this study, somatic embryos germinated to plantlets within 8 weeks of culture on the hormone-free MS medium (Figure 3A). However, the plant regeneration frequency was lowest when somatic embryos induced on MS medium containing picloram or combination of 2,4-D and picloram were cultured on MS basal medium (Table 3 ), and this possibly due to the residual effects of auxins. Activated charcoal (AC) has the potential to absorb some inorganic ions, growth hormones and phenolics. Aboshama (2011) suggested that there was an important role of $\mathrm{AC}$ in reducing the inhibitory effect of residual auxins and stimulating embryo conversion. Thus, inclusion of AC to the regeneration medium may increase the plant regeneration frequency.

Plantlet development and acclimatization - The germinated plantlets further developed on the half- 
Table 3. Plant regeneration frequency of embryogenic callus obtained in MS medium containing auxins cultured on the hormone-free MS medium after 8 weeks of culture (frequência de regeneração de plantas de calo embriogênico obtido em meio MS contendo auxinas quando cultivados em meio MS isento de reguladores, após 8 semanas de cultura). Seoul (Korea), Konkuk University, 2014.

\begin{tabular}{lcccc}
\hline \multirow{2}{*}{ Cultivars } & \multicolumn{4}{c}{ Plant regeneration (\%) } \\
\cline { 2 - 5 } & Treatment 1 & Treatment 2 & Treatment 3 & Mean \\
\hline Geumgodeahwang & $83.8 \pm 1.2$ & $20.9 \pm 1.0$ & $27.8 \pm 1.2$ & $44.1 \pm 34.5 \mathrm{~b}$-d \\
Geumokhwang & $87.2 \pm 1.0$ & $73.8 \pm 2.2$ & $32.9 \pm 1.2$ & $64.6 \pm 28.3 \mathrm{a}$ \\
Dabonghwang & $69.1 \pm 2.4$ & $36.2 \pm 0.8$ & $27.4 \pm 2.0$ & $44.2 \pm 22.0 \mathrm{~b}-\mathrm{d}$ \\
Bonganhwang & $63.5 \pm 3.2$ & $39.0 \pm 1.0$ & $50.1 \pm 1.8$ & $50.9 \pm 12.3 \mathrm{a}-\mathrm{d}$ \\
Chunjudaego & $78.4 \pm 1.6$ & $45.5 \pm 1.4$ & $43.4 \pm 1.6$ & $55.8 \pm 19.6 \mathrm{a}-\mathrm{d}$ \\
Chunjuhwang & $86.7 \pm 1.8$ & $40.6 \pm 2.8$ & $46.8 \pm 2.0$ & $58.0 \pm 25.0 \mathrm{a}-\mathrm{c}$ \\
Chunjujunggo & $61.6 \pm 4.4$ & $37.3 \pm 1.6$ & $57.0 \pm 1.4$ & $49.7 \pm 12.9 \mathrm{a}-\mathrm{d}$ \\
Yeoeuijuhwang & $56.4 \pm 1.6$ & $16.4 \pm 3.0$ & $38.2 \pm 1.8$ & $37.0 \pm 20.0 \mathrm{~d}$ \\
Okayhwang & $68.2 \pm 1.0$ & $24.5 \pm 3.4$ & $22.4 \pm 1.6$ & $38.4 \pm 25.9 \mathrm{~cd}$ \\
Yangchunhwang & $71.0 \pm 3.0$ & $23.7 \pm 3.2$ & $34.7 \pm 2.2$ & $43.1 \pm 24.8 \mathrm{bd}$ \\
Younganhwang & $76.7 \pm 2.4$ & $57.8 \pm 2.4$ & $45.0 \pm 1.0$ & $59.8 \pm 15.9 \mathrm{ab}$ \\
Seouldaego & $67.2 \pm 2.8$ & $33.4 \pm 1.5$ & $15.8 \pm 1.3$ & $38.8 \pm 26.1 \mathrm{~cd}$ \\
Spring Gold & $60.5 \pm 3.4$ & $43.0 \pm 2.0$ & $30.6 \pm 2.2$ & $44.7 \pm 15.0 \mathrm{~b}-\mathrm{d}$ \\
Turbo & $78.6 \pm 1.6$ & $56.2 \pm 1.6$ & $40.2 \pm 2.0$ & $58.3 \pm 19.3 \mathrm{a}-\mathrm{c}$ \\
Manchuhwang & $62.1 \pm 1.0$ & $47.0 \pm 2.0$ & $23.3 \pm 1.6$ & $44.1 \pm 19.6 \mathrm{~b}-\mathrm{d}$ \\
Higuma & $66.3 \pm 2.6$ & $27.6 \pm 2.4$ & $16.3 \pm 1.4$ & $36.7 \pm 26.2 \mathrm{~d}$ \\
\hline Mean & $70.1 \pm 9.7 \mathrm{a}$ & $38.9 \pm 15.1 \mathrm{~b}$ & $34.5 \pm 12.1 \mathrm{~b}$ &
\end{tabular}

Treatment 1=2,4-D $(1.0 \mathrm{mg} / \mathrm{L})$; Treatment $2=$ Picloram $(5.0 \mathrm{mg} / \mathrm{L})$; Treatment 3=2,4-D $(1.0 \mathrm{mg} / \mathrm{L})+$ Picloram $(2.5 \mathrm{mg} / \mathrm{L})$. Average values followed by same letters within a column are not significantly different according to Duncan's multiple range test $(\mathrm{p}<0.05)$ (valores médios seguidos de letras iguais na coluna não diferem entre si, pelo teste de Duncan, 5\%).

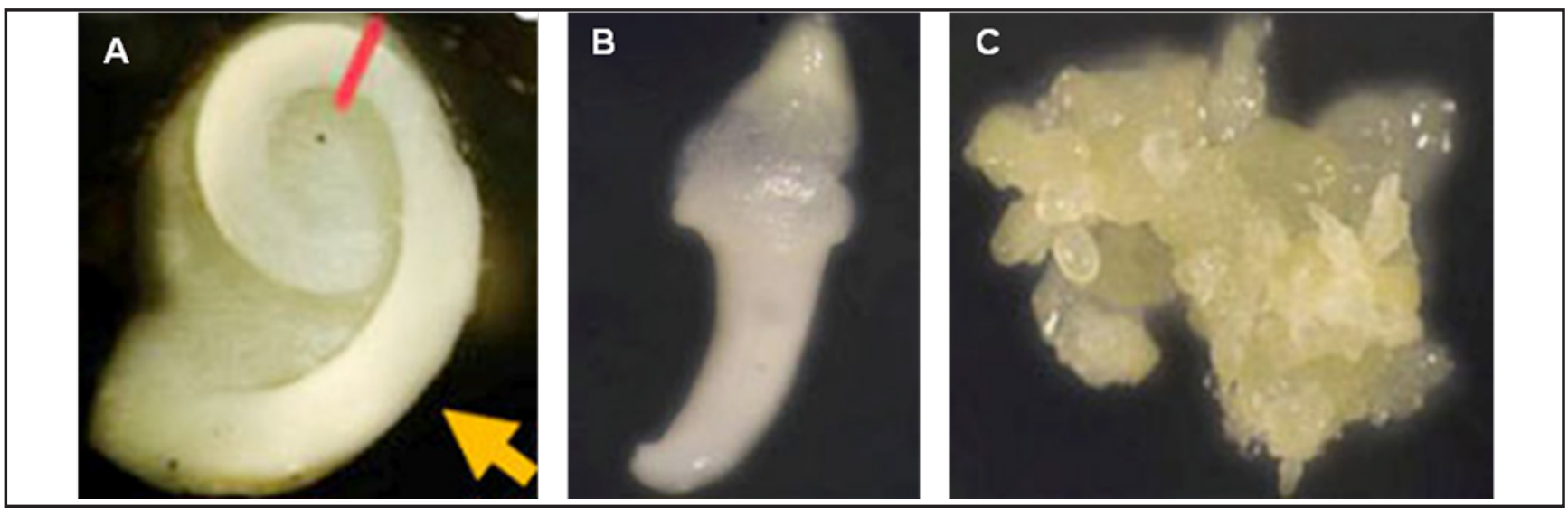

Figure 1. Different stages of somatic embryogenesis from zygotic embryo explants of $A$. cepa. (A) mature zygotic embryo (arrow represents the explant); (B) callus initiation after 2 weeks of culture and (C) embryogenic callus with somatic embryos after 8 weeks of culture \{fases da embriogênese somática a partir de explantes de embriões zigóticos de $A$. cepa. (A) embrião zigótico maduro (seta representa o explante); (B) iniciação de calo, após 2 semanas de cultura e (C) calo embriogênico com embriões somáticos após 8 semanas de cultura\}. Seoul (Korea), Konkuk University, 2014.

strength MS medium containing 3\% sucrose (Figure 3B). After 4 weeks of culture, the regenerated plantlets were transferred to pots containing peat, perlite and vermiculite $(1: 1: 1)$ and acclimatized in the culture room with $98 \%$ survival rate (Figure 3C).
In conclusion, an efficient plant regeneration protocol has been developed for 16 onion cultivars using mature embryo explants. Auxin had a significant effect on embryogenic callus induction and plantlet conversion. Picloram was shown to be the most effective than picloram $+2,4-\mathrm{D}$ and 2,4-D in the induction of embryogenic callus. The genotypic differences were observed in the frequency of embryogenic callus induction at different media composition. Thus, embryogenic callus induction is 


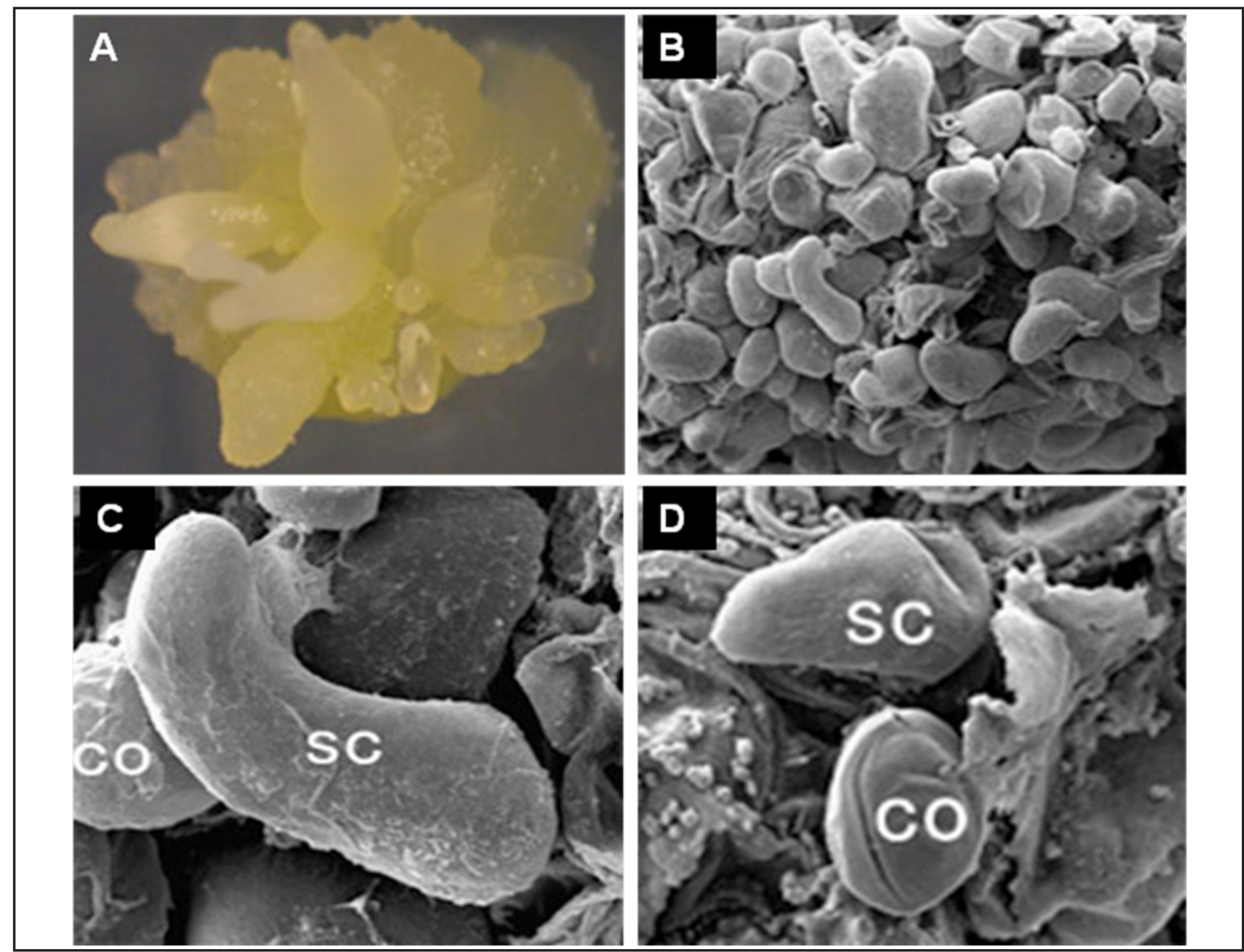

Figure 2. Scanning electron micrographs of SE in onion. (A) embryogenic callus with somatic embryos; (B) scanning electron micrograph of embryogenic callus showing various stages of somatic embryos; (C) scutellum (SC) associated with coleoptile (CO) and (D) a well developed coleoptile (CO) and scutellum (SC) \{micrografias de exploração eletronica de SE em cebola. (A) calo embriogênico com embriões somáticos; (B) micrografia eletrônica de varredura de calos embriogênicos mostrando vários estágios de embriões somáticos; (C) escutelo (SC) associado com coleóptilos (CO) e (D) um coleóptilo bem desenvolvido (CO) e escutelo (SC)\}. Seoul (Korea), Konkuk University, 2014.

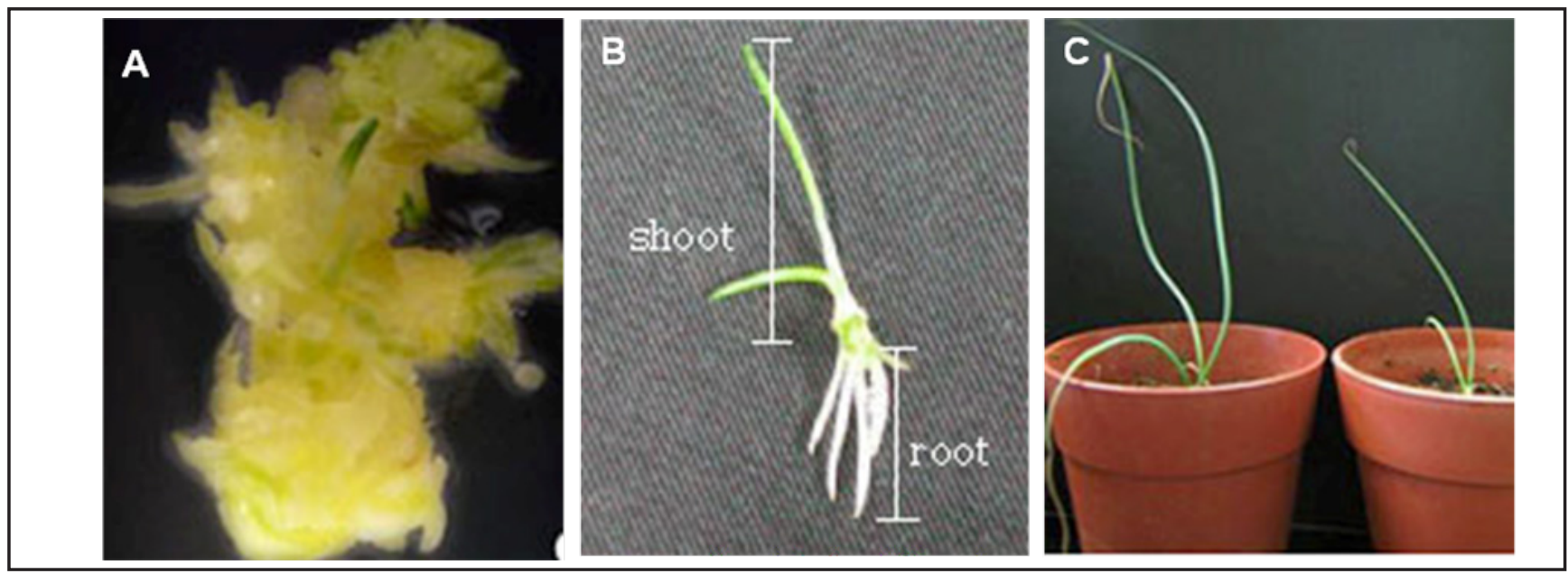

Figure 3. Plant regeneration from embryogenic callus of $A$. cepa. (A) germination of somatic embryos on MS medium; (B) somatic embryo derived plantlet cultured on half-strength MS medium after 4 weeks of culture and (C) acclimatized plantlets \{regeneração de plantas a partir de calos de A. cepa. (A) germinação de embriões somáticos em meio MS contendo metade da dose; (B) plântula obtida de embrião somático cultivada em meio MS após 4 semanas de cultura e (c) plântulas climatizadas\}. Seoul (Korea), Konkuk University, 2014. 
dependent on genotype and plant growth regulators. The best medium for 'Geumgodeahwang', 'Geumokhwang', 'Dabonghwang', 'Chunjujunggo', 'Okayhwang', 'Yangchunhwang', 'Younganhwang', 'Seouldaego', and 'Turbo' was MS medium with picloram, while the best one for 'Bonganhwang', 'Chunjudaego', 'Yeoeuijuhwang', 'Spring Gold', 'Manchuhwang', and 'Higuma' was MS medium with 2,4-D + picloram. In 'Chunjuhwang' the highest frequency of embryogenic callus was observed in MS medium with 2,4-D. Light and scanning electron microscopy analysis confirmed the presence of various stages of somatic embryos. Maturation and conversion of somatic embryos were achieved after transfer of embryogenic calli to the PGR-free MS medium. Embryogenic callus obtained from the 2,4-D-medium converted into plantlets at higher frequency than those from picloram- or 2,4-D + piclorammedium. The plant regeneration frequency of embryogenic callus induced on MS medium supplemented with 2,4-D varied from 56.4 to $87.2 \%$. The present study can be used for genetic transformation studies.

\section{ACKNOWLEDGEMENTS}

This paper was supported by the KU Research Professor Program of Konkuk University.

\section{REFERENCES}

ABOSHAMAHMS. 2011. Somatic embryogenesis proliferation, maturation and germination in Cajanus cajan. World Journal of Agricultural Sciences 7: 86-95.

ALBRECHTOVA J; LATR A; NEDOROST L; POKLUDA R; POSTA K; VOSATKA M. 2012. Dual inoculation with mycorrhizal and saprotrophic fungi applicable in sustainable cultivation improves the yield and nutritive value of onion. The Scientific
World Journal Article ID 374091, 8 pages, doi:10.1100/2012/374091

ASWATH CR; MO SY; KIM DH; PARK SW. 2006. Agrobacterium and biolistic transformation of onion using non-antibiotic selection marker phosphomannose isomerase. Plant Cell Reports 25: 92-99.

BENITEZ V; MOLLA E; MARTIN-CABREJAS MA; AGUILERA Y; LOPEZ-ANDREU FJ; COOLS K; TERRY LA; ESTEBAN RM. 2011. Characterization of industrial onion wastes (Allium cepa): dietary fibre and bioactive compounds, Plant Foods for Human Nutrition 66: 48-57.

CABRAL GB; CARNEIRO VTC; LACERDA AL; DO VALLE CB; MARTINELLI AP; DUSI DMA. 2011. Somatic embryogenesis and organogenesis in apomictic and sexual Brachiaria brizantha. Plant Cell Tissue and Organ Culture 107: 271-282.

CHAUDHURY A; QU R. 2000. Somatic embryogenesis and plant regeneration of turftype bermudagrass: Effect of 6-benzyladenine in callus induction medium. Plant Cell Tissue and Organ Culture 60: 113-120.

COMPTON ME. 1994. Statistical methods suitable for the analysis of plant tissue culture data. Plant Cell Tissue and Organ Culture 37: 217-241.

EADY CC; BUTLER RC; SUO Y. 1998. Somatic embryogenesis and plant regeneration from immature embryo cultures of onion (Allium cepa). Plant Cell Reports 18: 111-116.

GRIFFITHS G; TRUEMAN L; CROWTHER T; THOMAS B; SMITH B. 2002. Onions-A global benefit to health. Phytotherapy Research 16: 603-615.

HUSSEY G; FALAVIGNA A. 1980. Origin and production of in vitro adventitious shoots in the onion, Allium cepa. Journal of Experimental Botany 31: 1675-1686.

LELU-WALTER MA; THOMPSON D; HARVENGT L; SANCHEZ L; TORIBIO M; PAQUES LE. 2013. Somatic embryogenesis in forestry with a focus on Europe: state-of-theart, benefits, challenges and future direction. Tree Genetics \& Genomes 9: 883-899.

LUTHAR Z; BOHANEC B. 1999. Induction of direct somatic organogenesis in onion (Allium cepa). Plant Cell Reports 18: 797-802.

MARINANGELI P; ZAPPACOSTA D; GALMARINI C; CURVETTO N. 2005. Callus induction and plant regeneration in onion (Allium cepa). Acta Horticulturae 688: 301-308.

MURASHIGE T; SKOOG F. 1962. A revised medium for rapid growth and bio assays with tobacco tissue cultures. Physiologia Plantarum 15: 473-497.
OZIAS-AKINS P; VASIL IK. 1982. Plant regeneration from cultured immature embryos and inflorescences of Triticum aestivium (wheat): evidence for somatic embryogenesis. Protoplasma 110: 95-105.

OZIAS-AKINS P; VASIL IK. 1983. Improved efficiency and normalization of somatic embryogenesis in Triticum aestivum (wheat). Protoplasma 117: 40-44.

PHILLIPS GC; LUTEYN KJ. 1983. Effect of picloram and other auxins on onion tissue cultures. Journal of the American Society for Horticultural Science 108: 948-953.

PIKE LM; YOO KS. 1990. A tissue culture technique for the clonal propagation of onion using immature flower buds. Scientia Horticulturae 45: 31-36.

RAMAKRISHNAN M; CEASAR SA; DURAIPANDIYAN V; DANIEL MA; IGNACIMUTHU S. 2013. Efficacious somatic embryogenesis and fertile plant recovery from shoot apex explants of onion (Allium cepa). In Vitro Cellular and Developmental BiologyPlant 49: 285-293.

SAKER MM. 1997. In vitro regeneration of onion through repetitive somatic embryogenesis. Biologia Plantarum 40: 499-506.

SANTAS J; ALMAJANO MP; CARBO R. 2010. Antimicrobial and antioxidant activity of crude onion (Allium cepa) extracts. International Journal of Food Science and Technology 45: 403-409.

TANIKAWA T; TAKAGI M; ICHII M. 1998. Varietal differences in plant regeneration from solid and suspension cultures in onion (Allium cepa). Journal of the Japanese Society for Horticultural Science 67: 856-861.

VAN DER VALK P; SCHOLTEN O; VERSTAPPEN F; JANSEN R; DONS J. 1992. High frequency somatic embryogenesis and plant regeneration from zygotic embryoderived callus cultures of three Allium species. Plant Cell Tissue and Organ Culture 30: 181-192.

ZHANG W; LIN X; TAKANO H; TAKIO S; ONO K. 2004. Efficient plant regeneration from suspension cells of Allium cepa. Plant Cell Reports 23: 371-376.

ZHENG S; HENKEN B; SOFIARI E; JACOBSEN E; KRENS FA; KIK C. 1998. Factors influencing induction, propagation and regeneration of mature zygotic embryoderived callus from Allium cepa. Plant Cell Tissue and Organ Culture 53: 99-105.

ZHENG S; KHRUSTALEVA L; HENKEN B; SOFIARI E; JACOBSEN E; KIK C; KRENS FA. 2001. Agrobacterium tumefaciensmediated transformation of Allium cepa: the production of transgenic onions and shallots. Molecular Breeding 7: 101-115. 